\title{
Difficult or Delayed Positioning
}

National Cancer Institute

\section{Source}

National Cancer Institute. Difficult or Delayed Positioning. NCI Thesaurus. Code C63244.

Problem associated with users experiencing difficulty or delay to position the device to a specified location. 